FILM

\title{
Science at Sundance
}

The 2008 Sundance Film Festival, ending this week in Park City, Utah, included a healthy handful of science-themed films. Since the successes of 2005's feel-good Antarctic birdfest, March of the Penguins, and 2006's feel-bad Al Gore lecture An Inconvenient Truth, scientific documentaries have been in the ascendant - especially those about the environment.

Among the documentaries angling for a screen at the local multiplex, or at least a slot on television, are two that tackle conservation issues. Fields of Fuel is a paean to biodiesel starring the young activist Josh Tickell. Flow: For the Love of Water is a global look at how water scarcity drives corruption and big profits for certain corporations, a theme also explored in the sciencefiction film Sleep Dealer. Meanwhile, The Linguists documents two researchers travelling the globe recording languages that are about to become extinct. "It points out a global crisis that people may have only been vaguely aware of," says one of the pair, David Harrison of Swarthmore College near Philadelphia.

More upbeat fare is to be found in the shorts. A series on the

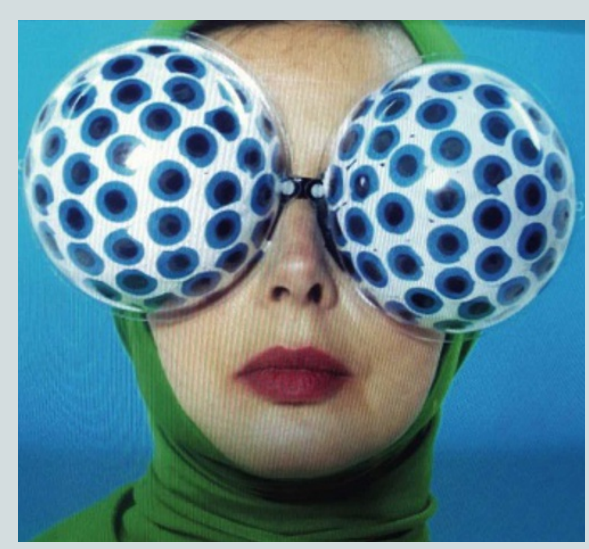

Bustamante has run a booth at the festival where attendees leave video messages for the future that, she promises, will be lovingly transferred from medium to medium as technology changes in the coming 500 years.

Finally, a hip short film that is actually a preview for a forthcoming flash-based computer game, Gas Zappers, spotlights the goofier side of global warming. It depicts a polar bear (what else?)

sex lives of insects, collectively titled Green Porno, sees Isabella Rossellini - also the director - dressed as a dragonfly (pictured) in the mood for love. Another, artsy short, Untitled \#1, imagines a strange world in 2507. Creator Nao defeating carbon-emitting villains with the help of such figures as Intergovernmental Panel on Climate Change chairman Rajendra Pachauri - who is clad as Moses and uses his tablets to beat back waves threatening to flood Venice.

\section{PREVIEW}

\section{Revealing reptiles}

\author{
Life in Cold Blood \\ television series written and presented \\ by David Attenborough
}

\section{Ed Yong}

"What do you think this is?" asks David Attenborough, handing me a heavy rock. Sitting in his London home, filled with wildlife paintings and tribal artefacts, I have been drawn into a game of 'guess the fossil'. The specimen turns out to be vertebrae from an ichthyosaur found in his neighbour's garden. "I went over and there was this, just lying about!"

Attenborough is as expected from his onscreen appearances - knowledgeable, eloquent, a consummate storyteller and extremely excited about wildlife. He is as happy enthusing about turtle mating as he is about the grisly habits of the caecilian, a burrowing worm-like amphibian whose young feed by tearing strips of fatty skin from their mothers. The most interesting thing he's eaten himself? "Big moth caterpillars in New Guinea. You put them on a fire and they come out like Twiglets."

The turtle and caecilian sequences feature in Life in Cold Blood, his new television series about reptiles and amphibians. "These are the last major classes of terrestrial animals that we haven't given a series to," he explains. The programmes are the culmination of the Life series, which began almost 30 years ago with Life on Earth. Attenborough says that he wants to make a box set indexing every species and topic covered. "I will be very pleased to be able to put that on a shelf."
Snakes, lizards and frogs might be less of a draw than meerkats and monkeys, but he relishes the challenge. "In a way, it's a great advantage because it means that a lot of their stories haven't been told. In my view, publicservice broadcasting shouldn't just be about making programmes about popular animals."

Only once does he pause, when I ask him if a shoot has ever disappointed him. He describes a trip in 1955 to the Aru Islands in Indonesia to film birds of paradise. "We turned up in Jakarta with a camera, didn't speak a word of the language and didn't have a letter of introduction from anybody. It was ridiculous." The government accused them of being spies and refused entry - even Attenborough can be defeated by bureaucracy. "We hastily thought of something else and went off to film Komodo dragons but we didn't get that either. It was hopelessly amateur and cack-handed but quite good fun."

Technology has improved since then, reducing the need for staged sequences. The question of artifice in natural-history programmes flusters Attenborough. He is incensed by an article complaining that a spitting cobra sequence used a captive animal. "I am not making an adventure programme ... I'm trying to demonstrate that there's a snake that squirts [venom] through its fangs like a hypodermic needle."

Attenborough is pragmatic. "I remember one woman who wrote in after watching a lion kill a wildebeest and said that it was absolutely scandalous. It would be much better to [train] lions to eat grass!" Talking of the need for balance: "It would be improper and disgraceful if you just dwelt on the violence and yet, if you don't show it, you are so distorting reality that you are producing fairytales. If people saw what we put on the cutting room floor."

To him, animals are gripping enough without help. "They are unpredictable, very often new, extraordinarily beautiful, dramatic and they share something with us, which is life." He sees his programmes as restoring our childlike fascination with living things, allowing people to "get back in touch, which is essential if they're going to take responsibility for nature".

Attenborough doubts we will arrest the decline in the world's biodiversity. "The thing that really appalls me is that there are three times as many people alive on Earth as when I started making programmes. The space left for other species has been eaten up. Just that is enough to dampen any joie de vivre I have."

$\mathrm{He}$ is equally modest about his fame. Dismissing his status as the result of "doing it forever and fairly regularly". He recognizes the tougher competition today, noting that an advertisement for a researcher on the Life of Birds attracted 3,000 applicants, one-third of whom had doctorates. "I feel almost guilty because I started when nobody wanted to do it."

He regains his spark when talking of his fellow film-makers. "There's no shortage of talent. All one asks is that they treat the animals with respect, and if they treat them with knowledge and admiration then that's a bonus." As for himself, he has no plans to go quietly into the sunset. He is scripting a programme on evolution to tie in with Darwin's bicentennial in 2009.

Ed Yong is a freelance science writer based in London. He blogs at http:// notexactlyrocketscience.wordpress.com.

A longer version of this story appears on network. nature.com. Life in Cold Blood is first broadcast on 4 February (BBC 1); DVD released on 25 February. 